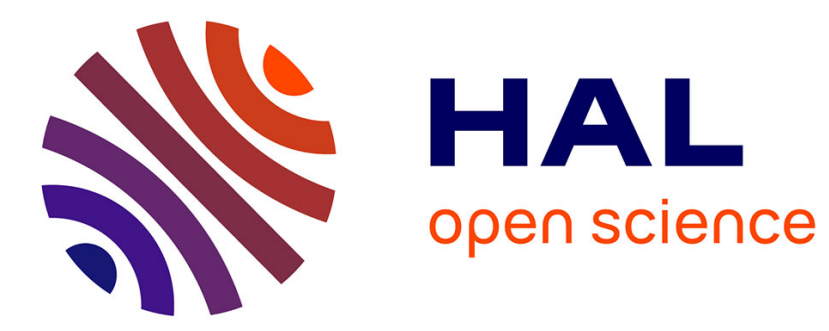

\title{
PSYCHOLOGY, ACTIVITY AND APPREHENSION OF OBJECTS: ON MEINONG'S REFUSAL OF REFLEXION
}

Bruno Langlet

\section{To cite this version:}

Bruno Langlet. PSYCHOLOGY, ACTIVITY AND APPREHENSION OF OBJECTS: ON MEINONG'S REFUSAL OF REFLEXION. Meinong-Studien, 2014. hal-02397020

\section{HAL Id: hal-02397020 \\ https://hal-amu.archives-ouvertes.fr/hal-02397020}

Submitted on 6 Dec 2019

HAL is a multi-disciplinary open access archive for the deposit and dissemination of scientific research documents, whether they are published or not. The documents may come from teaching and research institutions in France or abroad, or from public or private research centers.
L'archive ouverte pluridisciplinaire $\mathbf{H A L}$, est destinée au dépôt et à la diffusion de documents scientifiques de niveau recherche, publiés ou non, émanant des établissements d'enseignement et de recherche français ou étrangers, des laboratoires publics ou privés. 


\title{
PSYCHOLOGY, ACTIVITY AND APPREHENSION OF OBJECTS: ON MEINONG'S REFUSAL OF REFLEXION
}

\author{
Bruno Langlet
}

[ Penultimate draft - the ultimate version has been published in Meinong Studies V: M. Antonelli \& M. David (eds), Logical, ontological and historical contributions on the philosophy of Alexius Meinong, 2014, De Gruyter ]

\section{Summary}

In his 1904 paper, Über Gegenstandstheorie, Meinong said that Gegebenheit is the universal feature of objects: it is the property of being potentially given to the mind. Later, in Selbstdarstellung, Meinong stated that it is essential to objects that they could be graspable: the mind's having an object is the mind's being directed toward an object that is presented. Notions of Gerichtetsein, Meinen and Präsentation capture what it is for an object to be apprehended, and Meinong conceived of psychological states as they could insure the apprehension of objects. This view is strongly connected with the role Meinong attributed to the notion of "activity," which he distinguished from the notion of "act". I propose here an investigation about the historical, progressive and interpretative occurrence of the notion of activity in Meinong's works. This is connected with the issue concerning correct groundings of representations of relations and complexions, the refusal of reflexion and the criticisms of psychologism. In the mature period, such an activity is necessary to explain how representations are directed toward an object and why objects have to be grasped and not internally produced.

\section{Introduction}

As Meinong worked to ground Object Theory and went deeper into its entailments, he never ceased exploring psychology nor conceiving of the adequate relationship those topics of investigations should have. Discussions on psychology began in early texts, never ceasing as Object 
Theory appeared and remaining very much alive throughout the decades. Appearing within are clear and early claims formulated against psychologists and philosophers interested in psychology - claims stated again and again by Meinong throughout his life, some receiving progressive clarification, gaining weight or undergoing transformation. The very notion of degrees of evidence, which Brentano could never accept, is one example: this idea which appeared in the text on the epistemological value of memories, ${ }^{1}$ has been reasserted and reused by Meinong. Another example, which more closely aligns the issue discussed herein, is the very notion of reflexion. After some hesitation, such a notion has been constantly and adamantly refused by Meinong particularly concerning Marty in Über Annahmen; this refusal is deeply linked with issues that could precisely appear as conditions leading to the progressive formulation of Object Theory and to the emergence of Apprehension Theory. Historically speaking, reflexion upon internal contents or mental acts is an activity that appeared necessary to several important philosophers connected with Meinong in order to understand how representations could capture relations or complexions. Regarding this line of thought, Meinong appeared first to endorse the validity of the notion of reflexion, then suddenly made a conceptual move in a different direction: he conserved the notion of activity, exploring its function and disconnecting it from reflexion, then conceived of it as a necessary condition for the grasping of extrojected objects.

This conceptual move is grounded on specific conditions, requiring further clarification, and has been progressively connected with the distinction between content and object. A grounding relation between contents of ideas is progressively substituted for the reflexive process, a model which leads toward extrojection of objects through accurately determining the right kind of activity involved in the representation of non-intuitive complexions and relational complexes. Within the refusal of the necessity of reflexive processes lies the conceptual move that led to Meinong's thinking about the inherent activity of some psychological states as a condition for the direct grasping of extrojected entities and for

1 Meinong, (1886). 
the adequate relation with the objective side of knowledge. This schema is operative through different levels and is strongly linked with the apparition of the very notion of assumption (Annahme) as assumptions are one of the active states of mind that enable representations to have actual objects. Through investigating various aspects of this notion of activity's emergence within Meinong's thinking, one is in a position to understand roots of the relationships between Object Theory, Psychology and Apprehension Theory, as well as to observe, in some respect, not only how Meinong conceived a view in which some essential features are salient, but also his strong and progressive opposition to influent philosophical figures whose influence was more or less tacitly admitted.

\section{Act, Content, Object, and the Need for Activity}

Meinong recurrently claimed that there is a conceptual distinction between activity and $\mathrm{act}^{2}$. The concept of act refers to every mental state, however activity is not a property which pertains to all acts: within this discussion activity is viewed as an action of the mind while an act is simply seen as a modification of the mind - to judge and to assume involve activity and acts, but representations (Vorstellungen) are acts that do not involve activity. According to Meinong, representations and feelings are acts that are passive. Regarding this distinction, he primarily intended to show how such a distinction is to be conceived of through the articulation of the very concepts of psychology, Apprehension Theory and Object Theory.

Such a distinction appeared decisive for the connexion between activity and the so-called representational power of ideas, namely their property of having an object, and also appeared to be connected with a direct criticism of some empiricist presumptive assertions, namely those involving the per se representational power of ideas. It also seems that such a connexion is to be seen as a criticism directed to insufficiencies in

2 Meinong (1917), p 56 ; Meinong (1921) p. 21 : "Akt ist nicht Aktivität"; Meinong (1910), pp. 340. 
one of Brentano's major theses - the alleged inherent objectivity (Gegenständlichkeit) of every mental phenomenon. Objectivity refers here to the property of a representation having an object aimed at and consciously presented as such. The intentionality proposition of Brentano is rarely referred to in an explicit manner in Meinong's works, except in his 1917 text Über emotionale Präsentation in which Meinong focused on the objectivity of representations, which he saw as the true meaning of the Brentanian thesis of intentional inexistence; however he refused the absolute validity of such a proposition. According to Meinong, representation is an act, which means that it is a modification of the mind involving a particular content and an object. However a representation with a content and an object is not necessarily identical with the state of affairs where the mind has an experience by which the content of the representation is actually an object's presentative. Such a state of affairs obtains only if we have actual directedness toward the object and effective presentation of the object. Directedness (Gerichtetsein) and presentation (Präsentation) are internally linked - Meinong made the following distinction: although every representation is thought of as having an object, the mind can actually grasp the object only if the representational content is actually and actively directed toward the object thanks to another act exemplifying the activity feature, thus grounding the presentative experience of such an object. Subsequently, according to Meinong, all representations have an object although it may be said that there are representations without objects - that is, representations without actual actively intended objects - meaning, objects that are not grasped. The Brentanian intentionality thesis appears to be insufficiently grounded because conditions of apprehension must first be clarified.

Such a clarification entails a requalification of psychology that unfolds in the following manner. As made apparent in Über Annahmen, representations are mental acts, always passive ${ }^{3}$ as they are linked to a large number of objects in one's surroundings which are not actually

\footnotetext{
3 The passivity of representation has of course been recognized by Meinong in earlier texts - for example in Meinong (1891), pp. 397, where there is a reference to p.16 of Höfler's Psychologie, in which there is a sharp distinction between passive mental acts (Vorstellen and Fühlen) and active ones (Urtheilen and Begehren). In the second edition of Über Annahmen, the passivity of Vorstellungen is reaffirmed throughout chapter VII's argumentation.
} 
presented to the mind. This demonstrates what occurs, according to Meinong, in a perceptual context: various surroundings' elements are confusingly and potentially perceived, but conscious representation of some precise part of the surroundings can't be present to the mind without what contemporary psychologists would call attentional focus - what Meinong thought of as objectual directedness. The comparison being made is not meaningless as in Über Annahmen, Meinong made his point by referring to an instance of what psychology calls the "cocktail effect" - the capacity one has to disregard parts of what is prima facie within the perceptive field while focusing more closely on some precise content of perception - for example: one is actually listening to the philosophical conversation of a group behind him or her while appearing to watch and listen to the person in front of him or her. The surroundings' parts that are not under attentive focus are then disregarded, yet nevertheless, retain some kind of more of less confused presence within the mind. In Meinong's terms, the part of the surroundings truly present to the mind is the representation's object toward which the mind is actually directed and then being presented. From this point of view, all other representations merely have some dispositional representative power or dispositional objectivity and need the influence of some activity in order to acquire actual objectivity. Meinong described this fact through notions that are now admitted pertaining to metaphysics of powers or dispositions: he conceived of representation as having the dispositional property of objectivity - the "basis" for such a disposition being the content of the representation. Such content exists thanks to sensorial and passive data generated by the perceptive surroundings with the dispositional objectivity of the representation becoming an actual objectivity as the basis-content grounds the directedness toward the object; activity is always needed in order to enable this transition from the dispositional objective representational state to that of actual objectual representation.

Some acts have a precise role to play in such a state of affairs: indeed, assumptions or judgments are involved as they insure the directedness of representations - assumptions are the most basic activity, found in ordinary perceptive intentionality as well as in thoughts involving nonexisting objects which belong to the Aussersein. This implies that basic 
representations of properties of things are always propositional in kind. In Meinong's terms, to represent the colour green or the shape of a table is to think, at least implicitly, that the table has the property of being green or of being square. Objectives of Sosein are involved in this case and through such objectives, the greenness or the squareness is judged about, as the objective "the table is green" or "the table is square" is the judged object. The property is highlighted, but it is apprehended through the objective to which it pertains.

Activity then uses the passive content of dispositional representation in order to present the representation's object as pertaining to a complex object, that is, to an "objective." This is a condition enabling the mind to disregard other properties connected to the thing itself and to focus on one of them as being a property of the thing. The representational complex, activated thanks to assumption, grounds the apprehension of such a property that qualifies a thing, meaning that the property is presented after having been mentally separated from the very thing itself, while simultaneously asserting the property as a part of a complex object. This is what is presented to the mind and here there is a disconnection without real separation, what Meinong referred to as an "indicated connection"a complex object involving the mental separation of property from a thing, while remaining a whole pertaining to a united complex.

Due to its activity feature, the assumption's role is absolutely decisive to the understanding of the Meinongian special objectual realism, as it plays a central role in the grasping of effective, subsisting or non-existing objects. This activity role is clearly stated in Über Annahmen, with the concept being strictly connected with the Theory of Apprehension and the relationship between psychology and Object Theory.

As one delves further within Theory of Apprehension, necessarily thinking with concepts of Presentation and Directedness, activity becomes decisive to explaining the grasping of object, and as a consequence, psychology has been modified accordingly: the very concept of assumption, which is acknowledged as Meinong's great discovery, is just such a revelation of this change.

Such an interpretation of activity, longstanding in its development, is more or less present in Meinong's early psychological texts. However, 
what Meinong saw as the correct interpretation of such an activity is a very progressive process connected with the distinction between content and objects - the extrojection of objects peculiar to Object Theory and the elaboration of the view previously described. Clarification of the rationale of Meinong's manner of interpreting activity appears worthy, as it represents a strong conceptual choice between two possibilities: Meinong chose the path of direct apprehension of objects thanks to special psychological conditions disposing the mind to a capacity of being directed towards and grasping objects - he refused the path of internal and reflective work on contents and acts that supposedly insures that the mind has an object and pertains to some unity of consciousness. Meinong followed a theorisation that is closely aligned with naïve phenomenology and that avoids useless interpretative processes, even if it results in strong metaphysical involvements. The rejected interpretative processes carry the mark of a strong tradition, of numerous origins, that appeared to give it a position of authority - the Meinongian activity theory represents a bold move in the history of Austrian philosophy, possibly shedding a new light on the roots of Object Theory.

\section{The Silent Controversy about "Reflexion":} What is it to Think about Relations or Pluralities?

Activity is a notion that has been recognized by Meinong as necessary in order to understand the mind's operations, but the right interpretation of this activity and its conception as a condition for the grasping of objects is grounded in roots appearing in early texts, and is maintained and pushed further through the maturity of Object Theory.

From the point of view of the internal evolution of Meinong's works, the notion of activity's rise as a grasping condition for objects holds great interest, for it sheds light on the Meinongian refusal of psychologism, provides insight as to what psychologism truly is according to Meinong, while revealing key aspects of the conceptual and philosophical background he inherited - a background loaded with empiricist positions, 
Brentanian influences and post-Kantian logical theories grounded in psychology.

The very notion of activity is closely linked with a topic Meinong was interested in since his early works, namely the topic of relations. What are the real operations involved as the mind thinks about relations? It seems that one is unable to think of representations of relations in the same way as that of qualities: for a relation, in order to be thought of, seems to entail that one must mentally $d o$ something in order to have representations of relations. Consequently, the question concerning the nature of this doing emerges, and depending on the manner in which we think of this doing, we are committed to a specific interpretation of the activity at hand. Such an interpretation of the activity commits us either to psychologism or to realism concerning objects.

In texts from what is referred to as the mature period, wherein the Gegenstandstheorie is clearly defended, Meinong reacted strongly against approaches involving certain types of reflexive processes, namely those employed in Anton Marty's works, and inspirited by the Brentanian doctrines of double judgments. Yet there is a strong link in Meinong works between textual loci which are opposed to and argue against the relevance of reflexive processes (depending upon the various texts' topics) in the cases of representations, judgements, assumptions or emotions. Clearly emerging is Meinong's presentation of his own denials about reflexion as being connected; he referred to his own texts in order to ensure arguments, which appear to suggest that he viewed them through some systematic entailment, ${ }^{4}$ yet such a refusal, and his relationship with extrojection of objects and with the assertion of a true need of acts involving activities, is historically very progressive. In early texts, Meinong seemed to endorse the value of reflexive processes, or to think of them in a way which lead him to investigate such processes in association with internal perception's role - both having a decisive role in the representation of relations, such as similarity or differentness. He then came to forego his own conception and elaborated a new view that can retrospectively be identified, in some respect, as having led him to Object

$4 \quad$ Meinong (1906) P. 73 ff; Meinong (1910) §20.; Meinong (1921) : p. 22. 
Theory. In a more precise way, it is the elaboration of such a view that enabled him to understand how some kinds of activities pertaining to the thinking subject, while still necessary, must be in a position to ground a theory on the grasping of objects - in such a manner that this view could overcome what he perceived as some sort of disastrous psychologism.

From this point of view, the clarification of the background Meinong inherited, and from which some elements he was to admit, appears necessary. Naturally, identifying the exact origins of reflexion, as understood and received by Meinong, is somewhat puzzling. Within Fichte's works lies the theory, strongly inspirited by Kant ideas about conditions of objectivity, that reflexive process and position of an object are strictly linked: according to Fichte, a mental state must have its representative power grounded by some self-reflexion in order to have some focus toward a clearly defined object -such a reflexion grounds possibility for the mental state to be directed toward some object becoming conscious as a consequence. However, Fichte does not appear to be a thinker in whom Meinong found inspiration.

The presence of reflexion in the 1900's Austrian context appears as the result of various influences, which originated in several conceptual horizons, and against which Meinong reacted and conceived anew how the mind could truly grasp relations. In the second volume of his Hume Studien, relations are the most important topic that Meinong investigated as he tried to establish, for example, the correct conditions and description of the thinking of relations of resemblance, incompatibility and differentness. In this approach to relations, Meinong sometimes followed a path similar to that of the young Husserl: like others authors, they referred strongly to some Lotzean psychological and epistemological descriptions about what occurs in the mind as it compares represented properties and acquires the idea of a relation between two relata. Lotze claimed $^{5}$ that the activity of comparing two contents of ideas consequently raises a new mental and conscious state that is a specific modification of the mind which enables the subject to have an idea about both relata and relation in unity. The activity of comparing produces the

5 Lotze (1843). 
idea that content is internally perceived and linked to the contents of the relata's ideas. This comparison results both in the mind being affected, as well as in a new idea of distinct things that are presented as unified and as qualified by the idea of the relation.

It could seem that this way of thinking is not very far from what Meinong went on to establish in 1899 in his famous and provisory theory of higher order objects. ${ }^{6}$ Nevertheless, Meinong adopted an opposing view before conceiving of such objects and the occurrence of the Theory of Idea Production in the Graz school. Indeed, Lotze's previous reference is quoted by Meinong in his Hume Studien II, by Höffler and Meinong in Lögik, and by Husserl in his Philosophie der Arithmetik, in such a way that the process described by Lotze is thought of anew through a reflective process. The activity of perceiving, as carried out by the mind, is conceived of as something on which the mind must reflect in order to have representation of a relation and its relata - the very same idea that Lotze perceived as merely produced by the internal affection resulting from the afore mentioned comparison. In some respects, Lockean ideas of reflexion seem to lie behind the interpretative viewpoint proposed by Husserl and Meinong. As is commonly understood, according to Locke, an idea of reflexion is an idea being perceived by the mind as it is reflecting on its own operations - the operation of comparison, in the case of Lotze's description, is of course an operation affecting the mind and upon which, the mind itself must reflect according to the views of Husserl, Höfler and early Meinong. Lögik and Philosophie der Arithmetik were published in 1891 with Husserl's habilitationschrift "Über den Begriff der Zahl: psychologischen analysen" being written 4 years previously. The $\S 25$ of Höfler and Meinong's Lögik argue that concepts of numbers or pluralities are available to the mind thanks to the reflexive process directed toward the act performed by the mind. This is very close to Husserl's conception, with numerous references to the second volume of Hume Studien and to empiricists like Hobbes, Locke or Mill whose views appear to have been very influential on this issue. However, in 1891, Meinong seemed to give a reserved endorsement when confronted

$6 \quad$ Meinong (1899). 
with the role that inner perception or reflexion must play as the mind thinks about relations or pluralities.

Such a notion of reflexion is perhaps purely verbal, as it is not clear how exactly such a process is performed: is it a real reflexion upon the impression left by operations of the mind? Is this an internal direction of attention, enabling the mind to disregard its other contents, and then to produce selective enhancements of the internal perception? At this point, one could argue that the inner perception of such an operation is very different from the reflexive operation upon this idea, properly perceived as such, but it appears that such a distinction is not really realized, maybe because of the ambivalence of the Lockean terminology. For example, in Hume Studien II, Meinong began to formulate doubts and noticed that the detour through inner perception might be seen as a complication which is to be avoided; it is very interesting that in the note Mally wrote about this passage, inner perception and reflexion are willingly said to be on the same level. ${ }^{7}$ In this identification lies a future point of departure as the young Husserl radicalized the notion of reflexive activity, ${ }^{8}$ while Meinong progressively conceived of another view of activity, which allows the mind to quasi-directly grasp pluralities, complexes and relations thanks to presentative experiences which are the result of interaction between such an activity and previous mental states.

From the precedent point of view, this idea of reflexive process seems to go back to the empiricists, due to a passing-over of Kantian views which criticized empirical attempts to ground pure concepts of the

7 "Der Appell an die Innere Erfahrung oder an die Reflexion auf Erfassungsinhalte ist im Sinne späterer Auffassung hier wie überall dort..." Mally, in Meinong (1913), 175,

The notion of reflexion in early Husserl's works is clearly linked to Brentano's thesis of Intentionale inexistence, and I'll come back later to the brentanian origins of such a topic. Here, an example of Husserl's statements among others: "Auf der anderen Seite steht eine zweite Hauptklasse von Relationen, welche dadurch charakterisirt ist, daß hier das Relationsphaenomen ein psychisches ist. Richtet sich auf mehrere Inhalte ein einheitlicher psychischer Act, dann sind im Hinblick auf ihn die Inhalte verbunden oder auf einander bezogen. (...) Die Inhalte sind hier eben nur durch den Act geeinigt, und es kann daher erst durch eine besondere Reflexion auf ihn diese Einigung bemerkt werden". Husserl (1891), p.73. 
understanding by relationships between operations of the mind and perceptual experiences. However, it is clear that some psychologistlogicians, like Sigwart, proposed philosophical views inspirited by Kant; in such developments, reflexion again played a very important role, directly inherited from Kant's notion of reflexion and synthetic unity of consciousness. For example, Sigwart sustained that:

"The idea of difference is not something which is given. In our consciousness of several distinct objects it is certainly presupposed that we distinguish them; but at first it is the result only of the function which comes into consciousness, that is the co-existence of several objects, each of which is independently perceived. The idea of Difference, of likeliness or unlikeliness, does not develop until distinction takes place consciously, and is accompanied by reflexion." $" 9$

Comparison and reflexion were also, according to Kant, the positive condition in order to unify different things under some common concept thanks to an abstract representation of a property - then there is an important role which is attributed to reflexion and which is present within this philosophical background. It appears as a straight condition in order to enable the mind to have representations of pluralities that are not given prima facie, such a notion was further deepened and presented itself as a very technical and necessary concept.

Continuing with this view, in the second Volume of his Tonpsychologie, Stumpf said that Husserl is the philosopher who, in his Über den Begriff der Zahl, proposed a very clear insight into the decisive role of reflexion. ${ }^{10}$ Husserl was clearly interpreting the Lotzean

$9 \quad$ Sigwart (1873), P.36: “Die Vorstellung des Unterschieds ist nichts Gegebenes ; damit dass mehrere unterschiedene Objecte in Bewusstein, das in dem nebeneinander mehrerer Objecte, deren jedes für sich festgehalten wird, besteht. Die Vorstellung des Unterschieds aber, der Gleicheit oder Verschiedentheit, entwickelt sich erst, wenn das Unterscheiden mit Bewusstein vollzogen und auf diese Tätigkeit reflectiert wird (...)".

10 "Auch Husserl fasst Mehrheit als eine besondere Relation und macht auf eine für den Zahlbegriff wesentliche Eigentümlichkeit dieser Relation gegenüber denen der Ähnlichkeit, Steigerung u.a. aufmerksam : den Begriff von Mehrheit können wir nicht ohne Reflexion auf den zusammenfassenden psychichen Act 
description quoted above, ${ }^{11}$ however in his Philosophie der Arithmetik, he found inspiration in Kant, Bauman and Sigwart's writings ${ }^{12}$ (among others), who in some respects, proposed views wherein the notion of reflexion appeared in a more or less clear and technical way. This set of propositions could then be seen as the background against which Meinong reacted and which caused him to correct his own hesitations in Hume Studien II. What is clear is that the correct understanding of the activity involved in the conception of relations and complexions, became a very important subject and that the link between reflexion and the psychological state wherein a collative function performs unification; something seen at the start of the 1890's as a psychological mistake by Meinong.

Furthermore, this appeared retrospectively as pertaining to psychologism and what is surprising is that Meinong seemed to think early on that representation and knowledge of relations could not be explained by such a psychological expedient. It is well known that Frege, through some considerations concerning the very concept of number, attacked the Philosophie der Arithmetik on this topic, arguing that psychological reflexion or unifying activity cannot be substituted to the very concept of number and its logical properties. On this issue about the general role of reflexion, Meinong changed his position from that of a strictly psychological and epistemological point of view to one that refused to endorse theoretical views that would be qualified later on as being guilty of psychologism. Retrospectively, it may be concluded that he tried to remove psychologism from within psychology itself, something that is naturally paradoxical, yet one necessarily bears in mind that his psychological investigations were connected with theory of knowledge, this seeming opposition becomes less astonishing.

bilden, während wir die Begriffe von Gleichheit u.s.f rein aus den Inhalten selbst gewinnen. Für unsren Zweck kommt dieser Unterschied jedoch nicht in Betracht “. Stumpf (1890), n.2 p.5.

11 Which he quoted himself from the first volume of Stumpf's Tonpsychologie.

${ }^{12}$ See respectively pp. 37, 45 and 65 of Husserl (1891). 


\section{Activity, Extrojection and Apprehension of Objects}

Found within the text Meinong dedicated to Ehrenfels' paper on Gestaltqualitäten, ${ }^{13}$ initial investigations into the right interpretation of activity appeared and how he proposed to refuse the notion of reflexion. According to Ehrenfels, Gestaltquälitaten appear as properties of wholes that are grounded on characteristics of other things. Ehrenfels himself questioned the role that the active thinking subject plays in such a phenomenon, asking if an inner perception or reflexion toward the act is necessary - he came to a negative conclusion. Meinong's criticisms also endorse the refusal of reflexion and of inner perception, as Gestaltqualitäten cannot be present to the mind if such a reflexive process takes place.

Meinong then argues that clarification is needed concerning the role of activity and that the very notion of grounded contents and grounding contents, which appeared in Hume Studien, might prove useful. Such "grounding" showed itself, from this point of view, as a clear substitute for the reflexive process. Grounding content is content that, along with others, is used as a basis upon which another mind content is constructed and becomes conscious. The so-called Gestaltqualitäten, appear to be best understood through consideration of grounding relation: the actual activity of a subject is involved, but in such a manner that no reflexive process could be relevant. Psychological conditions in play within the thinking of such Gestaltqualitäten differ exceedingly from those conceived of from a reflexive viewpoint. The wholes constituted by the relationship between grounded contents and grounding contents are quite similar in nature to the entities that were supposedly represented due to a reflexive process of the mind upon the collating activity.

In writing on complexion and relations, Meinong avoided using reflexion, while conserving the idea of some notion of relating or collating function of the mind. This was affirmed by Mally, in his retrospective notes on this work, as some invading mark of psychologism.

${ }^{13}$ Ehrenfels (1890). 
That which emerges is Meinong's understanding of this collating activity without commitment to a reflexive activity.

The activity manifested by the mind and directed toward grounding contents is sufficient to have a grounded whole represented by the mind; this grounded whole being both unified and complex at the same time. The unity of the whole does not come from reflexion upon the unifying mind activity, meaning that wholes given in perception and wholes involving a thinking activity are thought of in parallel manner. This is where Meinong appears to oppose Stumpf in his text on analysis, ${ }^{14}$ as he recognizes that in order to form the idea of plurality as such, a collating and uniting psychic act is necessary, but that there is neither evidence nor argument leading to the idea that reflexion upon this act is necessary. Through further examination of the activity of analysis and its link with the way pluralities are given, Meinong defends a position where activity prepares the mind to apprehend something which is given as a whole, or where the uniting act is necessary but disconnected with the need to reflect upon it. Here the conceptual difference between wholes given in perception and wholes requiring the mind's acts, in order to be grasped, is modified in an important way. Wholes or relational intuitive complexes given in perception are grasped without reflexion as are non-intuitive complexes given to the mind as the result of a unifying activity - they are founded on the grounding contents upon which they depend, with unity and complexity being given without reflexion. This would lead to important insights from Meinong about real relations/complexions and ideal relations/complexions.

This issue is something Husserl recognized as absent from his Philosophie der Arithmetik, as he was under the influence of Brentano's thesis of intentionality, which according to Husserl, involved the notion of reflexion. This provides yet another key to understanding the influence of this notion of reflexion. How could Brentano have sustained such an idea? In his well-known Entwurf einer 'Vorrede' zu den Logischen Untersuchungen written in 1913, Husserl states that his interpretation of the representational and psychological conditions for grasping pluralities 
was mistaken because of the Brentanian distinction between what is physical and psychological with the latter involving intentionality. ${ }^{15}$ As reflexion is not a theme clearly used by Brentano, it appears that Husserl transposed the Brentanian theory about representations to the case of relations; according to Brentano, a representation has two objects: the first is the object of representation and the second is the very act of representation which enables the first object to be represented in an unity of consciousness. This is the doctrine of Concomitant Representation, according to which a representation is always accompanied by a concomitant representation that is necessary for the consciousness of objectivity, something that could easily be understood as a reflexive process. Brentano himself referred to Locke and his ideas of reflexion, or to Lotze who, according to him, claimed that a representation has to be accompanied by consciousness.

The representation of the secondary object ensures the conditions necessary for grounding unity of consciousness. Husserl seemingly twisted Brentanian doctrine by interpreting the relationship between the primary and secondary objects of representation as a reflexive process enabling the representation to have a unified object to present to the consciousness. This proposition, transposed to the relation and pluralities problem, could explain how a counting or collating mind act can ground a unitary content of thought thanks to reflexion upon the act, within which lies the origins of unity. This twist to Brentanian doctrine could explain why Stumpf, who was a true Brentanian, attributed the paternity of such an idea to Husserl and not to Brentano or others as it could well have explained why Husserl said his "scholar arms" have mistaken him.

Moreover, Brentanian doctrine received a strong modification on this issue by Twardowski and this modification is perhaps more relevant to

15 “... nach der mir schulmäßig Schablone, nach der alles anschaulich zu Fassende "Physisches" oder "Psychisches" sein musste, konnte es nichts physisches sein : Also entspringt der Begriff der Kollektion durch psychologische Reflexion in Brentano'schen Sinne, dur "Reflexion" auf den Akt des Kollogierens, ebenso der Begriff der Einheit durch Reflexion auf den Akt des Kolligierens, ebenso der Begriff der Anzahl nicht etwas wesentlich anderes als der Begriff des Kolligierens, den doch allein die Aktreflexion ergeben kann?" Husserl (1913), p. 295. 
understanding how Meinong was inspirated by him, rather than saying that Meinong discovered the distinction between object and content as well as the problem of representations without objects in the 1894 text $Z u$ Lehre vom Inhalt und Gegenstand der Vorstellungen. The distinction between object and content, as elaborated by Twardowski, is a redefinition of the distinction between primary and secondary objects of representation made by Brentano. Instead of having a secondary object as the object of concomitant representation and directed toward content and representation, as is found in Brentano's proposition, the secondary object is, according to Twardowski, the content of the representation as it is present inside the representation while the first object is the object toward which the representation is directed. In such a view, representations have a content related to an object, and there is no need for concomitant representation directed toward the first representation and its primary object. In other terms, there is no room for any interpretation of the representational fact in terms of reflexion.

This is such a change that the connection between content and object involves the extrojection of the object and its presentation thanks to content. This Twardowski insight is quite coherent with the Meinongian refusal of reflexion in the case of grounded and grounding contents, and is committed to the non-validity of the Brentanian version of primary and secondary objects of mental states. Accordingly, in the text concerning higher order objects, Meinong argued against the internal perception of acts, in this case, generic acts or representation - he stated that seeing an object does not involve representation and inner perception of the generic act of seeing. Although not explicitly referring to Brentano, this critical perspective seems directed toward ideas inspired by him. Our consciousness is then strongly linked with content and more directly, phemonologically, with objects. Real acts are not perceived and not presented - what is presented is the object of the act. This same argument is sustained when discussing psychical acts, meaning acts enabling presentation of complexions: such acts are not perceived although complexions are objects of the mind. One could say that if said acts are not internally perceived, they cannot be reflected upon. The only things 
truly perceived are physical objects - meaning exterior objects and perhaps feelings which are understood by Meinong as self-presented.

The relationship between contents and objects authorizes Meinong to refuse committing to representation of the act which, in one sense, is grounded on his phenomenology of the naïve man. There are various places in Meinong's works where he refers to the experience one makes as one thinks about exterior things, or perceives them or imagines them: the phenomenology of such activities is a phenomenology of the direct presentation of objects. As stated by Meinong, no one would say that they are thinking about their own internal ideas while being mentally directed toward objects. This is a classical argument about psychologism that is also found in Moore's Nature of Judgement and his argumentation against psychologism: according to Moore, one's assertion about the color of a rose is certainly not an assertion of or about one's ideas, ${ }^{16}$ but instead adresses real entities, (concepts for Moore). Meinong frequently used the same argument, presented through some kind of phenomenological evidence, in order to argue that no roundabout through internal perception or reflexion is ever consciously made; he found phenomenological evidence that one has connection with objects. Ideas possess the property of having contents through which objects are presented, but the properties of the ideas are different in respect to the properties of objects; content does exist while objects may not necessarily exist. Thus the true psychological description involves experiences which entail acts and contents - such experiences are directly linked with objects.

Such a move involves a great modification of the psychological model: there is a unity of consciousness as we have mental states directed toward objects or complexions, but objects and complexions do not

16 When, therefore, I say "This rose is red," I am not attributing part of the content of my idea to the rose, nor yet attributing parts of the content of my ideas of rose and red together to some third subject. What I am asserting is a specific connexion of certain concepts forming the total concept "rose" with the concepts "this" and "now" and "red"; and the judgment is true if such a connexion is existent. Similarly when I say "The chimera has three heads," the chimera is not an idea in my mind, nor any part of such idea. What I mean to assert is nothing about my mental states, but a specific connexion of concepts. Moore (1899), p. 179. 
involve a reflexive activity - they involve a gestaltic model that is, according to Meinong, a relation of grounding between contents which led to the notion of grounded object, once he made a technical and explicit use of the content-object distinction. This relation of grounding clearly involves an activity which is at stake within the very concept of the idea's production, comparing, counting and differentiating entities. Such an idea is directed toward an object which become graspable thanks to psychological presuppositions - the inferiora or pre-given contents, upon which the activity is exercising its task and as it is grounded as a superius, namely a higher order object. From this point of view, within the Meinongian proposition regarding ideal objects, it becomes apparent that grounding relation does the same thing as perception in the case of real objects: higher order objects are grasped thanks to grounding relation and idea production, and they are objects of such ideas. Returning to the previously discussed propositions of Über Annahmen, it was concluded that representation of an object, such as the color of a door, involves activity like that of assumption or judgement, because such objects are always grasped thanks to an objective to which they pertain. We now see that the very notion of activity is involved in a domain in which it was absent. Perceptive whole, properties or relations were supposedly given and represented wholes, pluralities and relations were supposed to be thought of thanks to a reflexive process upon the collating and uniting act. The reflexion disappeared from this "model" and the notion of activity, leading to the grasping of complex objects that invaded the domain where properties or relations first seemed to be directly given without any help from the subject.

One can then return to the idea that assumption and judgement enable representations to play a role that representations cannot fulfil by themselves, and find out how the activity enables the mind to be directed toward complex objects. In fine, Meinong tried to ground, from the point of view of Psychology, Object Theory and Apprehension Theory, what it is to be phenomenologically acquainted with such a complex object in a way that provides insights into theory of knowledge. According to Meinong, theory of knowledge is a part of Apprehension Theory because one must first understand how the mind apprehends objects before 
understanding how such a grasping could provide knowledge. Representations do have contents, but such contents require an activity of some kind that plays the same role regarding the grasping of complexes, that comparison or counting does in front of multiple entities. Relational complexes are presented by distinguishing the relata through a unity this condition is what an Objektiv of knowledge can propose, as in the case of what Meinong called "indicated connexion," wherein for example, a property is asserted to pertain to another entity. The presentation of a complex object such as "the crux that is red" cannot happen through a mere interplay between representations for various reasons, of which several were presented in Meinong's Über Annahmen, where he sought to identify the true relationship between contents that can afford for the presentation of such a complex object. If contents do have objects, then contents cannot simply interact in order to present the complex object because the properties of the objects are incompatible: the color red must be distinguished from the cruciform shape with the same applying for the shape, meaning that if one is dealing with single contents and trying to articulate them, the object "red" always has a definite form by virtue of its metaphysical (or real) relation with extension, and that the object, cruciform in shape, always has a distinct color for the very same reason. From this point of view, it is impossible to be acquainted with the complex object "the crux that is red" since the objects, which are to be related and also differentiated, have incompatible properties. A relationship must be identified between contents, one that is both grounded in another manner as well as explicative of how a unified and complex object can be presented to the mind. This problem concerns the different elements of the complex object.

Another problem is the unity of the complex object: how is it possible to ground such a unity? Meinong argues that no relation between contents could succeed in such a case because the alleged solution would be equivalent to the addition of some new content, one that is forcibly relational, and by this procedure, the connexion that is specific to the complex object cannot be obtained because of the regressus ad infinitum which is involved in this process. 
What is required is something that enables the mind to select solely shape and colour and to connect them although the distinction is still there - this is what activities like assumption and judgment do according to Meinong. Such activities seem to interact with contents in order to use their properties of external dependence (as defined in the text on analysis ${ }^{17}$ ) - that is, the fact that color, although being really connected to extension, can be thought of as color without using an explicit notion of extension. This would not be possible if one thought that the content red has an object which has to be mixed with other objects in order to have "the crux that is red," however this functions if activity affects contents in such a way that their properties of external dependence are used and present to the mind such contents, which will ground the directedness toward a single complex object: the Objektiv that is apprehended in a specific form thanks to this process. The objective "the crux that is red" would then be presented as a single objet wherein distinguished elements are also given, but in a very qualified way: the redness of the crux is asserted to the crux without being presented as the "red crux" (executed connexion) and elements are given within a specific relational order: they are separated and presented simultaneously in a strong connexion and throughout an objective unity.

We have here a conceptual grounding of what is phenomenologically given and at stake in any knowledge process, that is, the affirmation of the possession of a property by another entity - this could be seen as what has traditionally been defined as a Distinction of Reason, presented here in a very special sense: one cannot mentally create real distinctions between properties and things, this can only be accomplished through representation by thinking, assuming and judging. This is where object theory shows its strength: one is dealing with objects because mentally nothing can be done apart from thinking of them and thinking of them involves explaining the very conditions of correct objectivity, the psychological conditions that are necessary to explain that we are able to grasp complex objects through states of affairs, that is, through "objectives" - for grasped and represented states of affairs are always 
abstract entities where only a part of properties are selected as pertaining to a particular.

In a way, the activity lying in assumption or judgment does the same thing that the activity of comparison did: it articulates parts of ideas' contents in order to activate their dispositional objectivity by enabling them to present abstracted properties and directs the mind toward a complex entity wherein such properties are separated and presented in a very qualified way, pertaining to a superior unity which is completely dependent upon them.

The very notion of activity, pertaining to Apprehension Theory and essential to articulate Psychology and Object Theory, is at stake in the description of the conditions which enable the mind to be directed toward a complex object and to present it in a way that is consistent with phenomenological features and Object Theory.

Such an activity puts the mind in the capacity of being directed toward objects and to grasp them, potentially further being viewed as an attempt to overcome a problem about realism: if objects are independent of the mind, how is one to know anything about them? Meinong's position could be viewed as one authorizing the understanding that knowledge of how the mind grasps objects is necessary ${ }^{18}$.

Bruno Langlet

Aix-Marseille Université

brunolanglet@orange.fr

\footnotetext{
${ }^{18}$ Many special thanks to Kristen Hurst, Jean-Maurice Monnoyer and all the members of the SEMaIHP for their interest and encouragement on this subject.
} 


\section{References}

Ehrenfels von C. (1890) "Ueber Gestaltqualitäten”, Vierteljahrsschrift für Wissenschaftliche Philosophie, 14, 249-292.

Husserl Edmund. (1891), Philosophie der Arithmetik, Pfeffer, HalleSalle. "Entwurf einer 'Vorrede' zu den Logischen Untersuchungen." Herausgegeben von Eugen Fink. Tijdschrift voor Filosophie. Leuven. 1 (1939): 106-33; 319-39.

Meinong, Alexius (1968-1978), Alexius Meinong Gesamtausgabe, hrsg. von R. Haller und R. Kindinger gemeinsam mit R. M. Chisholm, Graz, Akademische Druck- und Verlagsanstalt [abbr.: GA].

Lotze Hermann (1841) Metaphysik, Weidmann'sche Buchhandlung, Leipzig.

Meinong Alexius. (1886), Zur Erkenntnistheoretischen Würdingung des Gedächnisses; repr. In GA II pp. 185-209.

Meinong, Alexius (1894), "Beiträge zur Theorie der psychischen Analyse", Zeitschrift für Psychologie und Physiologie der Sinnesorgane, 6, 1894, S. 340-385, 417-455; repr. in GA I, pp. 305388.

Meinong, Alexius (1899), "Uber Gegenstande hoherer Ordnung und deren Verhaltnis zur inneren Wahrnehmung", Zeitschrift für Psychologie und Physiologie der Sinnesorgane, 21, 1899, S. 182272; repr. in GA II, pp. 377-471.

Meinong Alexius (1913), Gesammelten Abhandlungen. Band. II:Abhandlungen zur Erkenntnistheorie und Gegenstandtheorie. Leipzig: Barth. GA II.

Meinong, Alexius (1917), Über emotionale Präsentation, in Sitzungsberichte der Akademie der Wissenschaften in Wien. Phil.hist. Klasse, 183, Abh. 2, 1917; repr. in GA III, pp. 283-476.

Meinong, Alexius (1921), "A. Meinong [Selbstdarstellung]", in R. Schmidt [Hrsg.] (1921), Die deutsche Philosophie der Gegenwart in 
Selbstdarstellungen, Bd. 1, Leipzig, Meiner, S. 91-150; repr. in GA VII, pp. 1-62

Moore, George Edward (1899), The nature of judgement, Mind, New Series, Vol. 8, No. 30, 176-193.

Sigwart Christoph von (1873), Logik, Volume 1, Die Lehre vom Urtheil, vom Begriff und vom Schluss. Verlag von J..B Mohr (paul Siebeck), Tübingen.

Stumpf Carl (1890), Tonpsychologie, vol. II, Leipzig: Hirzel

Twardowski Kasimir (1894), Zur Lehre vom Inhalt und Gegenstand der Vorstellungen-Eine psychologische Untersuchung, Wien: 1894 (anast. repr. Philosophia Verlag, München-Wien, 1982) 